\title{
Effects of Thymoquinone on Interleukin-1 and Interferon Gamma Gene Expression and Antibody Titers against Newcastle Disease in Broiler Chickens under Oxidative Stress
} http://dx.doi.org/10.1590/1806-9061-2015-0206

-Author(s)

\author{
Rastad $A^{\prime}$ \\ Sadeghi AA' \\ Chamani $\mathrm{M}^{\prime}$ \\ Shawrang P"
}

Department of Animal Science, Science and Research Branch, Islamic Azad University, Tehran, Iran

" Nuclear Agricultural Research School, Nuclear Science and Technology Research Institute, Atomic Energy Organization of Iran, Karaj, Iran.

\section{Mail Address}

Corresponding author e-mail address Ali Asghar Sadeghi

Department of Animal Science, Science and Research Branch, Islamic Azad University,

Tehran, Iran

Tel: $\quad$ +989195579663

Email: a.sadeghi@srbiau.ac.ir

\section{aKeywords}

Broiler, interferon gamma, interleukine-1, thymoquinone, tert-butyl hydroperoxide.
Submitted: December/2015

Approved: June/2016

\section{ABSTRACT}

An experiment was conducted to determine the effects of the dietary inclusion of different levels of thymoquinone (TQ) of broilers subjected to oxidative stress or not on the antibody titers against Newcastle disease and on the gene expression of interleukine-1 and interferon gamma. A total of 320 one-day-old broilers was randomly assigned to eight treatments with four replicates of 10 birds each, in a $4 \times 2$ factorial arrangement, consisting of four thymoquinone (TQ) levels $(0$, 5 , 8 , or $11 \mathrm{mg} / \mathrm{kg}$ body weight) and two levels tert-butyl hydroperoxide (t-BHP) injection (0 or $0.02 \mathrm{mmol} / \mathrm{kg}$ of body weight). Blood samples were collected from two birds per replicate to determine antibody titers against Newcastle disease. At the end of experiment, two birds per replicate were randomly selected, sacrificed and their spleens were collected to evaluate the genes expressioninterleukin-1 and interferon gamma $(p<0.05)$. The dietary inclusion of TQ of broilers subjected or not oxidative stress increased antibody production against Newcastle disease $(p<0.05)$. Both individual and combined dietary inclusion of t-BHP and TQ promote the differentiation and proliferation of spleen cells and the gene expression of interleukin-1 and interferon gamma $(p<0.05)$.

\section{INTRODUCTION}

Stress negatively affects broiler performance and increases mortality rates. Broilers may be exposed to several kinds of stress (Prieto \& Campo, 2010), such as oxidative stress. Oxidative stress is caused by an imbalance between the production of free radicals and the capacity of the antioxidant defense system to override them. Free radicals can bind with different parts of cells and disrupt their functions (Zhou et al., 2000). The strongest effects of free radicals are exerted on fats, proteins and DNA (Lobo et al., 2010). Free radicals can alter the expression of genes by binding to different DNA sites, disturbing protein synthesis, and consequently, affecting animal performance (Sharma et al., 2012).

Tert-butyl hydroperoxide is a chemical used in various experiments to cause oxidative stress in the body (Simeonova et al., 2014).

The body is protected against oxidative damage by enzymatic and non-enzymatic systems. Non-enzymatic antioxidant systems can be natural and synthetic. Natural antioxidants, such as vitamins A and C, are present in plants (Shrihari et al., 2012), such as buck seed (black cumin); which use has very beneficial effects. No negative effects of the dietary inclusion of black cumin on broiler performance were reported (Goreja, 2003). Black cumin was evaluated in several broiler nutrition studies, which reported improvement in body growth, protein synthesis and immune functions (Sogut et al., 2008). Black cumin extract contains several active compounds, such as TQ, which has antioxidant effects. 
Rastad A, Sadeghi AA,

Chamani M, Shawrang P
Effects of Thymoquinone on Interleukin-1 and Interferon Gamma Gene Expression and Antibody Titers against Newcastle Disease in Broiler Chickens under Oxidative Stress
There are several studies on the use of this substance as antioxidant in humans and some animals (Umar et al., 2012; Singh et al., 2014), but there are no reports on the effects of black cumin on the immune system or immune gene expression. Therefore, this study was performed to evaluate the effects of TQ on antibody titers against Newcastle disease (ND) and the gene expression of interleukin-1 and interferon gamma.

\section{MATERIALSAND METHODS}

This experiment was conducted on the farm of the Islamic Azad University of Darab, Fars, Iran. In total, 320 one-day-old Ross 308 broiler chicks were used. Birds were reared on floor pens for 42 days. Feed and water were supplied ad libitum. A three-phase feeding program was applied (starter, grower, and finisher), and composition of the basal diets is given in Table 1.

Table 1 - Ingredients and calculated nutrient composition of experimental diets

\begin{tabular}{|c|c|c|c|}
\hline & $\begin{array}{l}\text { Starter } \\
(0-10 \mathrm{~d})\end{array}$ & $\begin{array}{c}\text { Grower } \\
(11-24 d)\end{array}$ & $\begin{array}{l}\text { Finisher } \\
(25-42 \mathrm{~d})\end{array}$ \\
\hline \multicolumn{4}{|l|}{ Ingredients (\%) } \\
\hline Corn & 52.86 & 58.13 & 60.24 \\
\hline Oil, vegetable & 3.83 & 4.57 & 5.32 \\
\hline Soybean meal (44\%) & 37.35 & 28.99 & 30.86 \\
\hline DL-Methionine & 0.36 & 0.28 & 0.25 \\
\hline L-Lysine $\mathrm{HCl}$ & 0.25 & 0.15 & 0.14 \\
\hline L-Threonine & 0.1 & 0.00 & 0.04 \\
\hline Limestone & 1.6 & .97 & 1.43 \\
\hline Fish meal & 2 & 5 & 0 \\
\hline $\mathrm{NaCl}$ & 0.25 & 0.27 & 0.3 \\
\hline Vit. \& Min. premix & 0.5 & 0.5 & 0.5 \\
\hline DCP & 0.9 & 1.13 & 0.93 \\
\hline Total & 100 & 100 & 100 \\
\hline \multicolumn{4}{|c|}{ Calculated nutrient composition } \\
\hline Crude Protein, \% & 22.72 & 21 & 19 \\
\hline Energy, kcal/kg & 3025 & 3150 & 3200 \\
\hline Lysine(SID), \% & 1.43 & 1.24 & 1.09 \\
\hline Met+Cys(SID), \% & 1.07 & 0.93 & 0.86 \\
\hline Threonine(SID), \% & 0.78 & 0.71 & 0.62 \\
\hline Tryptophan(SID), \% & 0.32 & 0.45 & 0.26 \\
\hline Calcium, \% & 1 & 0.9 & 0.85 \\
\hline Av. Phosphorus, \% & 0.5 & 0.46 & 0.42 \\
\hline \multicolumn{4}{|c|}{$\begin{array}{l}\text { Vitamin \& mineral premix (content per } \mathrm{kg} \text { ): vitamin A, 1,800,000 IU; vitamin D3, } \\
400,000 \mathrm{IU} \text {; vitamin E, 3,600 IU; vitamin } \mathrm{K} 3,400 \mathrm{mg} \text {; thiamine, } 360 \mathrm{mg} \text {; riboflavin, } \\
\text { 1,320 mg; niacin, 6,000 mg; vitamin B6, } 600 \mathrm{mg} \text {; vitamin B5, 2,000; vitamin B12, } 3 \\
\text { mg; folic acid, } 200 \mathrm{mg} \text {; biotin, } 20 \mathrm{mg} \text {, choline, } 80 \mathrm{~g} \text {; zinc, } 17 \mathrm{~g} \text {; iron, } 10 \mathrm{~g} \text {; copper, } 2 \text { g; } \\
\text { manganese, } 20 \mathrm{~g} \text {; selenium, } 40 \mathrm{mg} \text {; iodine, } 200 \mathrm{mg} \text {. }\end{array}$} \\
\hline
\end{tabular}

Birds were weighed upon arrival at the farm, and randomly assigned to eight dietary treatments with four replicates of 10 birds each according to a completely randomized design in a $4 \times 2$ factorial arrangement (dietary inclusion of four TQ levels and two t-BHP levels). The treatments included: control group (diet with no TQ or t-BHP), group 2 (diet with 5 mg TQ/kg body weight), group 3 (diet with 8 mg TQ/ $\mathrm{kg}$ body weight), group 4 (diet with $11 \mathrm{mg} \mathrm{TQ} / \mathrm{kg}$ body weight), group 5 (diet with $0 \mathrm{mg} \mathrm{TQ} / \mathrm{kg}$ body weight + $0.02 \mathrm{mmol}$ t-BHP/kg body weight), group 6 (diet with $5 \mathrm{mg} \mathrm{TQ} / \mathrm{kg}$ body weight $+0.02 \mathrm{mmol}$ t-BHP/kg body weight), group 7 (diet with $8 \mathrm{mg} \mathrm{TQ} / \mathrm{kg}$ body weight $+0.02 \mathrm{mmol}$ t-BHP/kg body weight) and group 8 (diet with $11 \mathrm{mg}$ TQ/kg body weight + $0.02 \mathrm{mmol}$ t-BHP/kg body weight).

\section{Vaccination against Newcastle disease and infectious bursal disease}

Vaccinations were injected against Newcastle and infectious bursal diseases on days 7 and 19 .

\section{Preparation and injection of thymoquinone and tert-butyl hydroperoxide}

The prooxidant t-BHP and the antioxidant TQ (2-isopropyl-5-methyl-1,4-benzoquinone) were purchased from Sigma-Aldrich. TQ was diluted in $1 \mathrm{~mL}$ dimethyl sulfoxide and olive oil, and daily injected intraperitoneally. t- BHP also injected intraperitoneally at $0.02 \mathrm{mmol} / \mathrm{kg}$ body weight on days 18,21 and 24 .

\section{Sampling and measurement of blood parameters}

On days 28 and 42, two were chicks randomly selected from each replicate, and blood samples were taken from wing's vein. Blood serum was separated in centrifuge at $2000 \times \mathrm{g}$ for $30 \mathrm{~min}$. Serum samples were stored at $-20^{\circ} \mathrm{C}$ for determination of antibody titers against Newcastle disease.

\section{Gene expression}

At the end of experiment, two birds were selected from each replicate to collect their spleens. The spleens were placed in a liquid nitrogen tank. The samples were transported to the laboratory of the University of Shahid Beheshti of Tehran to determine the gene expression of interleukin-1 and interferon gamma using Reverse Transcription-polymerase chain reactions (RT-PCR) technique. Messenger RNA (mRNA) extraction was performed using an extraction kit (Vivantis Company, Malaysia). Then, cDNA synthesized by reverse transcriptase using commercial kits (Vivantis Company, Malaysia). Real-time PCR was performed using Power SYBR Green PCR Master Mix (Applied Biosystems, CA, USA). Beta-actin was applied as housekeeping gene. Primers sequences are shown in Table 2. 
Rastad A, Sadeghi AA, Chamani M, Shawrang P
Effects of Thymoquinone on Interleukin-1 and Interferon Gamma Gene Expression and Antibody Titers against Newcastle Disease in Broiler Chickens under Oxidative Stress
Table 2 - Primer sequences used for analysis of interleukin-1 and interferon gamma genes expression.

\begin{tabular}{ll}
\hline Primers & Sequences \\
\hline Interferon gamma (Forward) & 5-GATGTGCGGATACCTGAAGC -3 \\
Interferon gamma (Reverse) & 5-AGGGATGCCAACATGACTGA -3 \\
Interleukin-1 (Forward) & 5-TACGCATACTGTCACCATCA -3 \\
Interleukin-1 (Reverse) & 5-ATGGATGGGAAGGAGCTACAA -3 \\
Beta-actin (Forward) & 5-CCACCGCAAATGCTTCTAAAC-3 \\
Beta-actin (Reverse) & 5-AAGACTGCTGCTGACACCTTC-3 \\
\hline
\end{tabular}

\section{Statistical analysis}

Statistical analysis was performed using the software SAS (2001). Means were compared using Duncan's multiple-range test and significance was determined at $p \leq 0.05$ (Duncan, 1955).

\section{RESULTS}

\section{Antibody titers against Newcastle disease}

Table 3 shows the results of antibody titers against Newcastle disease. On day 28, broilers fed diets with TQ, with or with no t-BHP (oxidant agent) presented higher antibody titers. The dietary inclusion of TQ at the levels of 8 and $11 \mathrm{mg} / \mathrm{kg}$ body weight in the groups 3 and 4 promoted significantly higher antibody production under oxidative stress condition compared with group 5,and also with groups 6 and $7(p<0.05)$. The group 5 received only t-BHP, and groups 6 and 7 , in addition to t-BHP, also received TQ at the levels of 5 and $8 \mathrm{mg} / \mathrm{kg}$ body weight, respectively.

No significant antibody titer differences were observed between birds fed TQ at the levels of 5 and $11 \mathrm{mg} / \mathrm{kg}$ body weight under oxidative stress or not, respectively ( $p>0.05)$.

Therefore, the dietary inclusion of TQ at $11 \mathrm{mg} / \mathrm{kg}$ body has increased antibody production. There were no significant differences between the groups of 5,6 , and the with control group ( $p>0.05$ ).

Table 3 - Effects of thymoquinone and tert-butyl hydroperoxide on antibody titers against Newcastle disease.

\begin{tabular}{lcc}
\hline Treatments & Day 28 & Day 42 \\
\hline Control & $1.96^{\mathrm{b}}$ & $3.18^{\mathrm{c}}$ \\
2 & $2.42^{\mathrm{ab}}$ & $4.00^{\mathrm{ab}}$ \\
3 & $2.73^{\mathrm{a}}$ & $4.31^{\mathrm{a}}$ \\
4 & $2.63^{\mathrm{a}}$ & $4.23^{\mathrm{a}}$ \\
5 & $1.96^{\mathrm{b}}$ & $3.16^{\mathrm{c}}$ \\
6 & $2.02^{\mathrm{b}}$ & $3.24^{\mathrm{c}}$ \\
7 & $2.11^{\mathrm{b}}$ & $3.50^{\mathrm{bc}}$ \\
8 & $2.38^{\mathrm{ab}}$ & $3.48^{\mathrm{bc}}$ \\
SEM & 0.182 & 0.267 \\
\hline
\end{tabular}

Means with different superscripts in the same column are significantly different at $p<0.05$
On day 42, the groups receiving only TQ (groups of 2, 3 and 4) produced more antibodies than the control group $(p<0.05)$. Antibody titer of group 5 , receiving only t-BHP, was not significantly different from the control group ( $p>0.05)$. The groups receiving to TQ and under oxidative stress did not present significantly different antibody titer compared with the control group ( $p>0.05$ ).

\section{Gene expression}

Table 4 shows interleukin- 1 and interferon gamma gene expression of all experimental groups subjected to oxidative stress or not.

Table 4 - Effects of thymoquinone and tert-butyl hydroperoxide on interleukin-1 and interferon gamma gene expression

\begin{tabular}{lcc}
\hline Treatments & Interleukine-1 & Interferon gamma \\
\hline Control & $1^{\mathrm{e}}$ & $1^{\mathrm{e}}$ \\
2 & $1.163^{\mathrm{de}}$ & $1.236^{\mathrm{de}}$ \\
3 & $1.293^{\mathrm{d}}$ & $1.474^{\mathrm{d}}$ \\
4 & $1.861^{\mathrm{c}}$ & $1.678^{\mathrm{cd}}$ \\
5 & $1.371^{\mathrm{d}}$ & $1.579^{\mathrm{cd}}$ \\
6 & $2.175^{\mathrm{c}}$ & $1.797^{\mathrm{c}}$ \\
7 & $2.724^{\mathrm{b}}$ & $2.571^{\mathrm{b}}$ \\
8 & $3.461^{\mathrm{a}}$ & $2.966^{\mathrm{a}}$ \\
\hline
\end{tabular}

Means with different superscripts in the same column are significantly different at $p<0.05$

According to this table, TQ and t-BHP individually increased the gene expression of interleukin-1 and interferon-gamma, as well as their interaction. The experimental group 8, which was fed TQ at the level of $11 \mathrm{mg} / \mathrm{kg}$ body weight and t-BHP, presented the highest expression of both genes.

\section{DISCUSSION}

\section{Antibody titer against Newcastle disease}

All groups fed TQ produced more antibodies than the control group $(p<0.05)$. The reduced production of antibodies in body of chickens under oxidative stress is related with an increased production of inflammatory cytokines, particularly interferon gamma and interleukin-1 (Vuet al., 2014). These factors increase the secretion of corticotropin releasing hormone by the hypothalamus. This hormone, in turn, increases the secretion of adrenocorticotropic hormone by the pituitary gland. These events increase the levels of corticosterone in the adrenal glands. TQ inhibits free radicals and oxidative stress, and reducing the release of corticosterone that inhibits antibody production. Therefore, the improvement in antibody production 
Rastad A, Sadeghi AA,

Chamani M, Shawrang P
Effects of Thymoquinone on Interleukin-1 and Interferon Gamma Gene Expression and Antibody Titers against Newcastle Disease in Broiler Chickens under Oxidative Stress in the groups fed TQ may be related with reduced corticosterone release. According to Badr et al. (2013), the antibody production increases because TQ promotes an increase in the number and proportion of lymphocytes B, which produce antibodies. Also, although the levels of free radicals in the groups that did not receive t-BHP were low, TQ consumption led to an increase in the number and proportion of lymphocytes. In these groups, the low levels of TQ were used in animal body to inhibit the accumulation of free radicals. While, chicks in groups under oxidative stress had lower the numbers and proportion of lymphocytes than non-stressed chicks.

\section{Interleukin-1 and interferon gamma gene expression}

The results of this study show an increase in the expression of both these cytokine genes. The effects of t-BHP oninterleukin-1 and interferongamma gene expression are a result of the production of free radicals promoted by this chemical substance. Inflammation causes increased levels of inflammatory cytokines. These cytokines can increase the activity of the immune cells involved in the inflammation process. The inhibition of interleukine-1-beta activity causes colon infection in rabbits (Cominelli et al., 1992). Furthermore, interleukine-1 can control inflammation by increasing the blood vessel permeability of vessels and speed up the movement of immune factors (Kesavulu et al., 2000). Moreover, interleukine-1 increases the production of some chemokines and other products that play a role in infection and inflammation (Nygaard et al. 2013). Interleukine-1 also accounts for the fever observed during body contamination against pathogenic microorganisms (Oberholzer et al., 2000; Schaffner, 2006).

Interferon gamma is the main factor stimulating macrophage activity. It also plays several roles against microorganisms and tumor cells. This cytokine also promotes the growth and maturity of white blood cells (Nayler et al., 1984). The release of interleukine-12 by macrophages increase interferon gamma gene expression (Pien et al., 2000). Interferon gamma plays an important role on the control of inflammation by influencing the expression of several genes (Londhe \& Davie, 2011). Free radicals act as cellular messengers in inflammation processes (Ferrari \& Andrade, 2015). Free radicals also activate several inflammatory enzymes, such as protein kinase, protein phosphatase and other transcription factors (Khanna et al., 2015). Therefore, free radicals have been proven to increase the inflammation.

\section{CONCLUSIONS}

Both individual and combined dietary inclusion of tert-butyl hydroperoxide and thymoquinone promote the differentiation and proliferation of spleen cells and the gene expression of interleukin-1 and interferon gamma.

The dietary addition of thymoquinone increases the production of antibodies and white blood cells.

\section{REFERENCES}

Badr G, Mahmoud MH, Farhat K, Waly H, Al-Abdin OZ, Rabah DM. Maternal supplementation of diabetic mice with thymoquinone protects their offspring from abnormal obesity and diabetes by modulating their lipid profile and free radical production and restoring lymphocyte proliferation via PI3K/AKT signaling.Lipids in Health Disease 2013;18:12:37. doi:10.1186/1476-511X-12-37.

Cominelli F, Nast CC, Duchini A, Lee M. Recombinant interleukin-1 receptor antagonist blocks the proinflammatory activity of endogenous interleukin-1 in rabbit immune colitis. Gastroenterology 1992;103:6571.

Duncan DB. Multiple range test and multiple F-tests. Biometrics 1955;11:142.

Ferrari RS, Andrade CF. Oxidative stress and lung ischemia-reperfusion injury. Oxidative Medicine and Cellular Longevity 2015; ID 590987, $14 \mathrm{p}$.

Goreja WG. Black cumin: nature's miracle remedy. New York: 7 Amazing Herbs Press; 2003

Khanna HD, Karki K, Pande D, Negi R, Khanna RS. Inflammation, Free Radical Damage, Oxidative Stress and Cancer. Interdisciplinary Journal of Microinflammation 2015;Article ID 590987. 14 p.

Kesavulu MM, Giri R, Kameswara Rao B, Apprao C. Lipid peroxidation and antioxidant enzyme levels in type 2 diabetics with microvascular complications, Diabetes and Metabolism 2000;26, 387-392.

Lobo V, Patil A, Phatak A, Chandra N. Free radicals, antioxidants and functional foods:Impact on human health. Pharmacognosy Review 2010;4:118-126.

Londhe P, Davie JK. Gamma interferon modulates myogenesis through the major histocompatibility complex class II transactivator, CIITA. Molecular and Cellular Biology 2011;31:2854-2866.

Naylor SL, Gaty PW, Lalley PA. Mouse immune interferon (IFN-gamma) gene is on chromosome 10. Somatic Cell and Molecular Genetics $1984 ; 10: 531-534$

Nygaard, TK, Pallister KB, Zurek OW, Voyich JM. The impact of $\alpha$-toxin on host cell plasma membrane permeability and cytokine expression during human blood infection by CA-MRSA USA300. Journal of Leukocyte Biology 2013;94:971-979.

Oberholzer A, Oberholzer C, Moldawer LL. Cytokine signaling-regulation of the immune response in normal and critically ill states. Critical Care Medicine 2000;28:3-12.

Pien GC, Satoskar AR, Takeda K, Akira S, Biron CA. Selective IL-18 requirements for induction of compartmental IFN- $\gamma$ responses during viral infection. Journal of Immunology 2000;165:4787-4791. 
Rastad A, Sadeghi AA,

Chamani M, Shawrang P

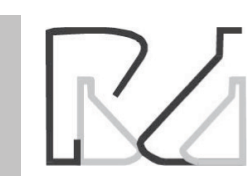

Effects of Thymoquinone on Interleukin-1 and

Interferon Gamma Gene Expression and Antibody Titers against Newcastle Disease in Broiler Chickens under Oxidative Stress
Prieto MT, Campo JL. Effect of heat and several additives related to stress levels on fluctuating asymmetry, heterophil: lymphocyte ratio, and tonic immobility duration in White Leghorn chicks. Poultry Science 2010;89:2071-2077

Schaffner, A. Fever-useful or noxious symptom that should be treated?."Therapeutische Umschau. Revue therapeutique 2006;63:185188.

Sharma P, Bhushan Jha A, Dubey RS, Pessarakli M. Reactive oxygen species, oxidative damage, and antioxidative defense mechanism in plants under stressful conditions. Journal of Botany 2012;ID 217037. 26p.

Shrihari, TG, Vasudevan V, Kailasam S, Devaiah D, Manjunath V, Jagadish GR. Antioxidants:Are we abusing It? Journal of Indian Academy Oral Medicine Radiology 2012;24:306-310.

Simeonova R, Kondeva-BurdinaM, Vitcheva V, Mitcheva M. Some in vitro/in vivo chemically-induced experimental models of liver oxidative stress in rats. Biomed Research International 2014;706302.

Singh R, Devi S, Gollen R. Role of free radical in atherosclerosis, diabetes and dyslipidemia. Diabetes/Metabolism Research and Reviews 2014;13:4249.
Sogut B, Celik I, Tuluce Y. The effects of diet supplemented with the black Cumin (Nigella sativa L.) upon immune potential and antioxidant marker enzymes and lipid peroxidation in broiler chicks. Journal of Animal and Veterinary Sciences 2008;7:1196-1199.

Umar S, Zargan J, Umar K, Ahmad S, Katiyar CK, Khan HA. Modulation of the oxidative stress and inflammatory cytokine response by thymoquinone in the collagen induced arthritis in Wistar rats. Chemico-Biological Interactions 2012;197:40-46.

Vu D, Shah T, Ansari J, Sakharkar P, Yasir Q, Naraghi R, et al. Interferongamma gene polymorphism $+874 \mathrm{~A} / \mathrm{T}$ is associated with an increased risk of cytomegalovirus infection among Hispanic renal transplant recipients. Transplant Infectious Disease 2014;16:724-32.

Zhou JF, Cai D, Zhu YG, Yang JL, Peng CH, Yu YH. A study on relationship of nitric oxide, oxidation, peroxidation, lipoperoxidation with chronic chole-cystitis, World Journal of Gastroenterolerology 2000;64:501507. 
